\title{
RELATIONSHIP BETWEEN THE RECENT DUNE ACTIVITIES AND THE RAINFALL FLUCTUATIONS IN THE SOUTHERN PART OF AUSTRALIA
}

\author{
Hiroo OHMORI*, Kazutaka IWASAKI** and \\ Kazuhiko TAKEUCHI**
}

\begin{abstract}
Summary
For the remobilization of dunes in the southern part of Australia, many causes have been pointed out. The climatological cause, however, has been discussed only insufficiently. In this paper the relationship between the recent dune activities revealed by geologic, geomorphologic, vegetation and hearing surveys, and the rainfall fluctuations induced by the analysis of both instrumental data and drought records was examined.

It was confirmed that the patched distribution of presently active dunes with a sharp contrast to the surrounding stable dunes covered with vegetation in the semi-arid and humid zones is not due to the local difference in climate, but due to the patched distribution of thickness of the latest Pleistocene to late Holocene dune sands. Although some of presently active dunes are reported to have been active even before the European settlement, most of them started their sand drifts after the vegetation clearance by them. Therefore, almost all of them can be called "remobilized dunes".

The marked dune activities have been taking place whenever the residual mass curve of rainfall continuously decreased for more than one year resulting in the amount of the sum of the decrease exceeded 500 and/or $600 \%$ of the mean annual rainfall of each region. It is since the end of the 19 th century that the periods of decreasing in rainfall and severe droughts, when marked sand drifts also occurred, became frequent in the southern part of Australia. It was relatively humid from the end of the 18th century to the end of the 19th century and the dry phase started from the beginning of the 20th century. The remobilized dunes have increased in both number and coverage since the beginning of the 20th century when the dry climate became more frequent. This circumstance continues now at least in the southern part of Australia.
\end{abstract}

\section{Introduction}

Many dunes recently started remobilization in the southern part of Australia. For their remobilization, many causes such as bushfire, both natural and human, vegetation clear-

* Dept. Geogr., University of Tokyo.

** Graduate Student, University of Tokyo.

*** Dept. Geogr., Tokyo Metropolitan University. 
ance, exploitation, overgrazing by sheep, rabbit infestation and even off-road vehicles have often been suggested (Land Conservation Council, 1974; Williams, M., 1978; Gilbertson, 1981): On the other hand, dust-storms and sand movements occurred frequently in southeast Queensland in the 1930's. It is emphasized that the sand movement was not due to cultivation or drought, or to the depredations of grazing animals, but due to a change in climate (Ward and Russel, 1980). Gilbertson (1981) points out by examining the rate of dune advance after the European settlement on the southern coast in South Australia that the present rate of dune erosion is difficult to be seen as mainly a legacy of European pastoralism. These studies, however, are not researches investigating systematically the relationship between the change of dune activity and that of climate. There is no study discussing the relationship between the dune activity and the climatic fluctuation throughout the period after the European settlement for many places over the southern part of Australia. Therefore, it is not clear how to evaluate the causes men. tioned above.

In this paper the relationship between the recent dune activities revealed by geologic, geomorphologic, vegetation and hearing surveys, and the rainfall fluctuations induced by

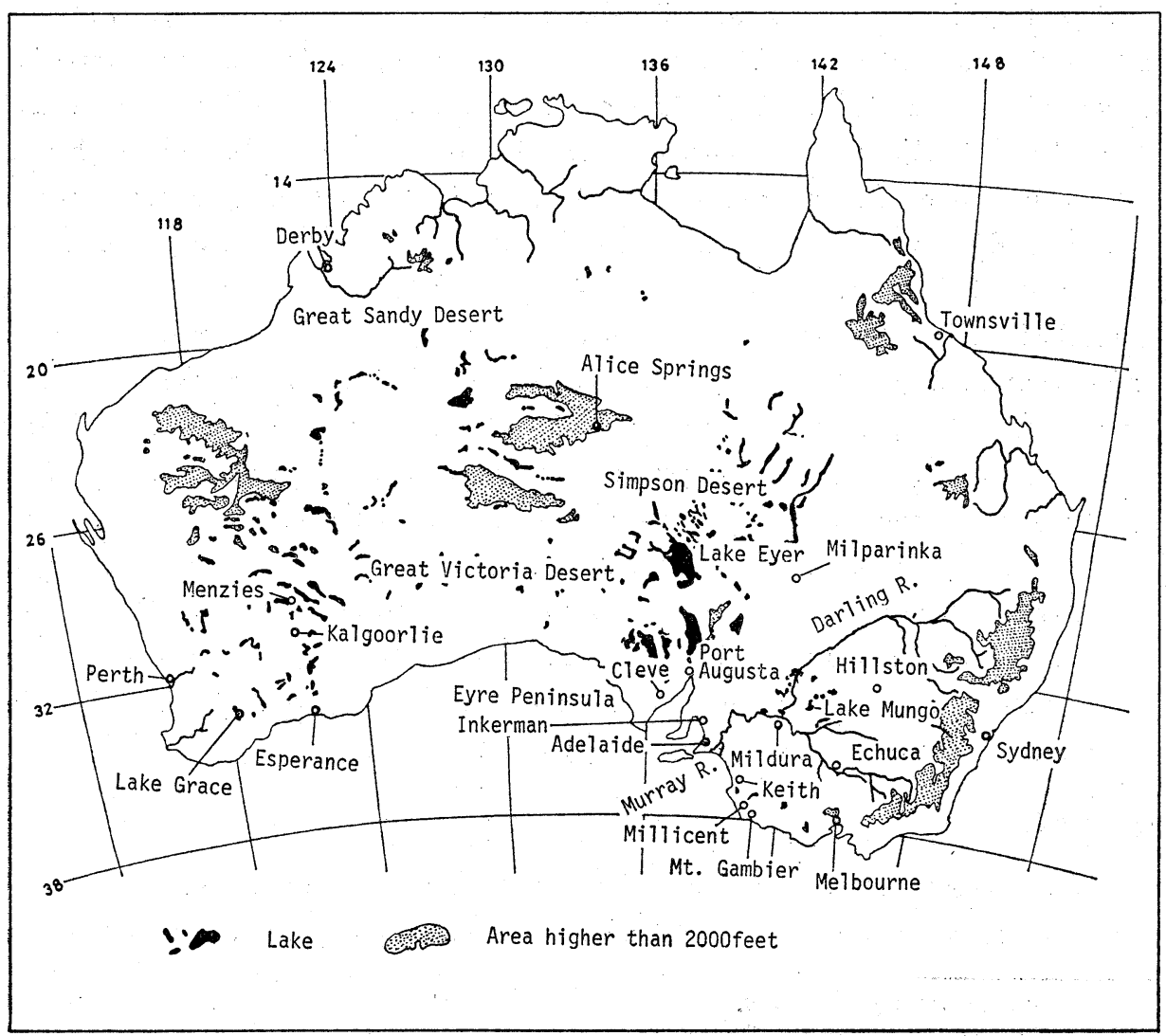

Fig. 1 General map showing the places mentioned in this paper 
the analysis of both instrumental records and drought data were examined and the climatological cause of the dune remobilization was discussed. The main surveyed areas are shown in Fig. 1.

\section{Characteristics of the distribution of active dunes}

The inland dunes of the Australian continent are classified into two kinds of shapes and brigins. One is called "longitudinal dunes" which are distributed widely over the deserts and the riverine plains and the other is called "lunettes" lying on the downwind margin of lakes (Bowler, 1971, 1976, 1978; Bowler and Magee, 1978; Bowler et al., 1976, 1978; Wasson, 1976, 1979). The dunes along the seacoast of the continent are generally called parabolic dunes from their shapes (Thom, 1978; Gilbertson, 1981; Thom et al., 1981).

These dunes are classified into two types of dune activities. One is stable dune and the other is active dune. The stable dunes which are completely covered with Eucalyptus schrubland (mallee) are distributed mainly in the southern semi-arid and humid zones. There are two distinctly different types of active dunes. In the inner arid district, where tussock grassland and Acacia schrubland (mulga) spread over, most of the crest parts of fossil dunes are active with less magnitude for the vast coverage of area, which are classified as "regional active dunes" according to Ohmori (1980). On the other hand, in the semi-arid and humid zones, dunes with very active sand movement are distributed in patches with a sharp contrast to the surrounding stable dunes. Such active dunes are called "local active dunes". Sand drifts on the local active dunes are markedly active compared with those on the regional active dunes. Erosional depressions have been caved on the windward side, where many dead trees with exposed roots are scattered. Accumulation ridges and swells are formed on the leeward side where there are many trees, dead and living, with the lower parts of their trunks buried in presently drifting sands. On these active dunes, presently drifting sands are supplied from the erosional areas on the windward ${ }_{2}$ side of the fossil dunes.

Fig. 2 shows the distribution of dunes by the different types of dune activity based on the field observations by air and surface surveys in 1979 and 1980. A marked zonal distribution of dune is recognized. The regional active dunes are restricted to the inner arid zone and the local active ones and the stable ones are found successively outward. This corresponds to the zonal distribution of climate and vegetation. The local active dunes are distributed near the boundary between the regional active dune fields and the stable dune ones in both the central and southern parts of the continent. Paticularly in the southern part of the continent the occurrence of local active dunes is regarded as a peculiar phenomenon to the critical boundary of climatic zones, that is, the transitional zone from the arid zone to the humid one, where landform and vegetation are extremely sensitive to both effects of the climatic change itself and of the human impact through agriculture. This general characteristic of the distribution of local active dunes has been confirmed by 


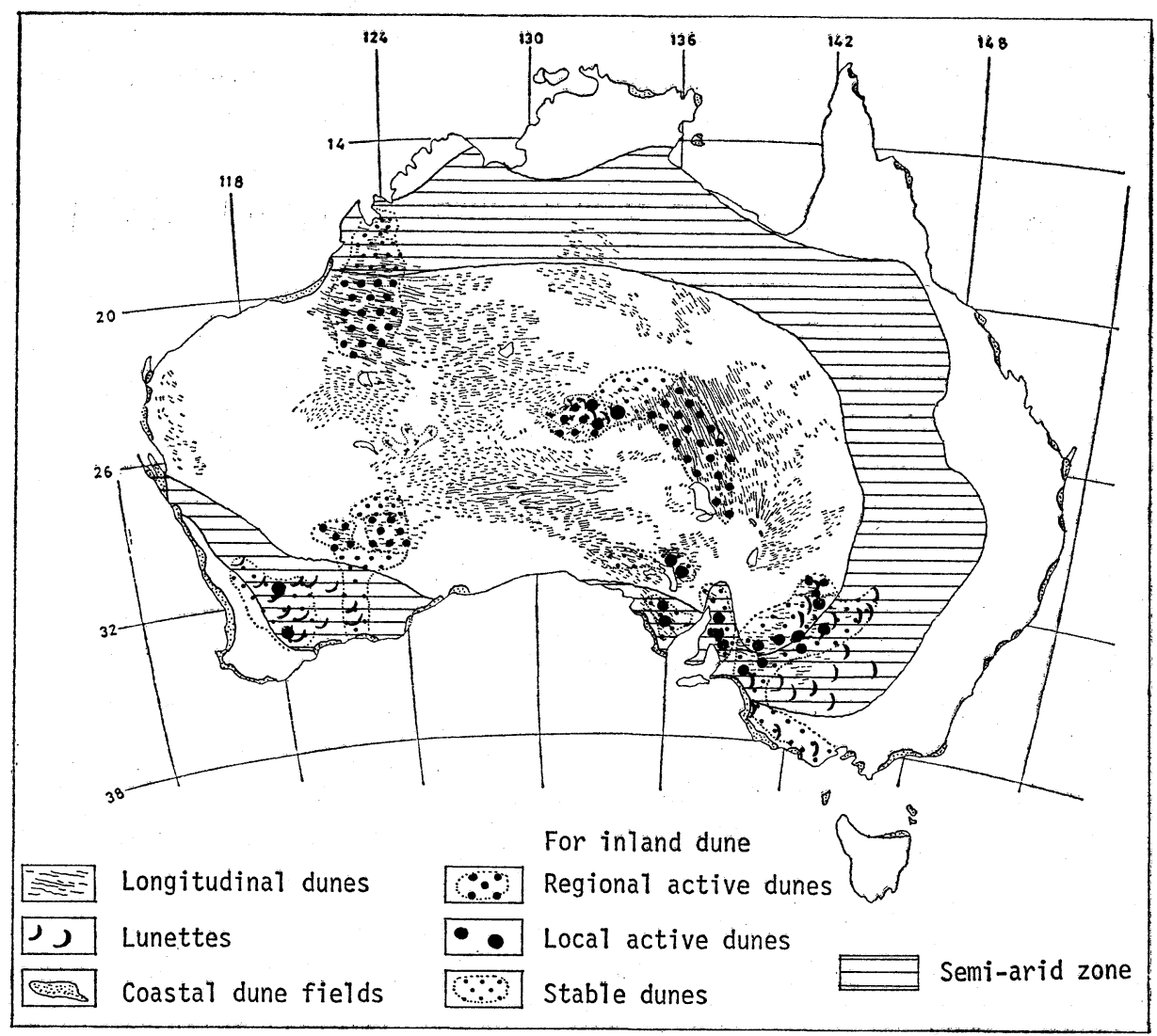

Fig. 2 Distribution of the active dunes

The base map of the distribution of dunes for each kind of shape and origin, that is, the longitudinal dune and the lunette, is the partly modified one from that of Bowler (1971) and Dept. National Development of Australia (1973). The climatic division follows from Bowler's one (1971) drawn based on Thornthwaite's classification. The area circled by dotted lines shows the fields where the present states of dune activity, active or stable, were confirmed by this survey.

the informations of various authorities and persons such as the Commonwealth Scientific and Industrial Research Organization, Australia (C.S.I.R.O.) and the Department of Agriculture, South Australia.

Along the seacoast, the active dunes are distributed intermittently around the continent. For example, along the east coast where the coastal dune fields are distributed almost continuously from Cape York to the northern coast of Tasmania, the active dunes with intensive sand drift can be found to exist in every dune field. This condition is the same along the west coast and the south coast, where a relay station established in 1877 was abandoned in 1924 when it was buried in drifting sands near Eucla (Learmonth and Learmonth, 1971; Raymond and Morrison, 1979). The present sand drift is found not only on foredunes, but also on inner parabolic dunes where sands are supplied not from the beach, but from the erosional areas on the windward side of fossil dunes. Namely, 
most of the active dunes along the seacoast have been caused as a result of remobiliza. tion. These active dunes with erosional depressions and accumulation ridges are classified as the local active dunes. They are distributed sporadically in stable dune fields and the activities of sand movement are as intensive as those on the local active dunes in inland. The relationship between the disbribution of active dunes and the climatic zones such as that shown by the inland dunes is not recognized for the coastal dune fields, though the rainfall varies with regions along the seacoast.

Taking account of the characteristics of the distribution of local active dunes described above, the fields of geological and vegetation surveys were selected in the southern part of Australia.

Although the dune fields spreading over the Australian continent is estimated to have seen formed at least at 300,000 B.P. (Bowler, 1976), the strata of dune deposits since the late Pleistocene are composed of four units based on the criteria of palaeosol and unconformity. They are called, from the bottom, latest Pleistocene dune deposits, Holocene older dune sands (Do), Holocene younger dune sands (Dy) and Present drift sands (PD). The

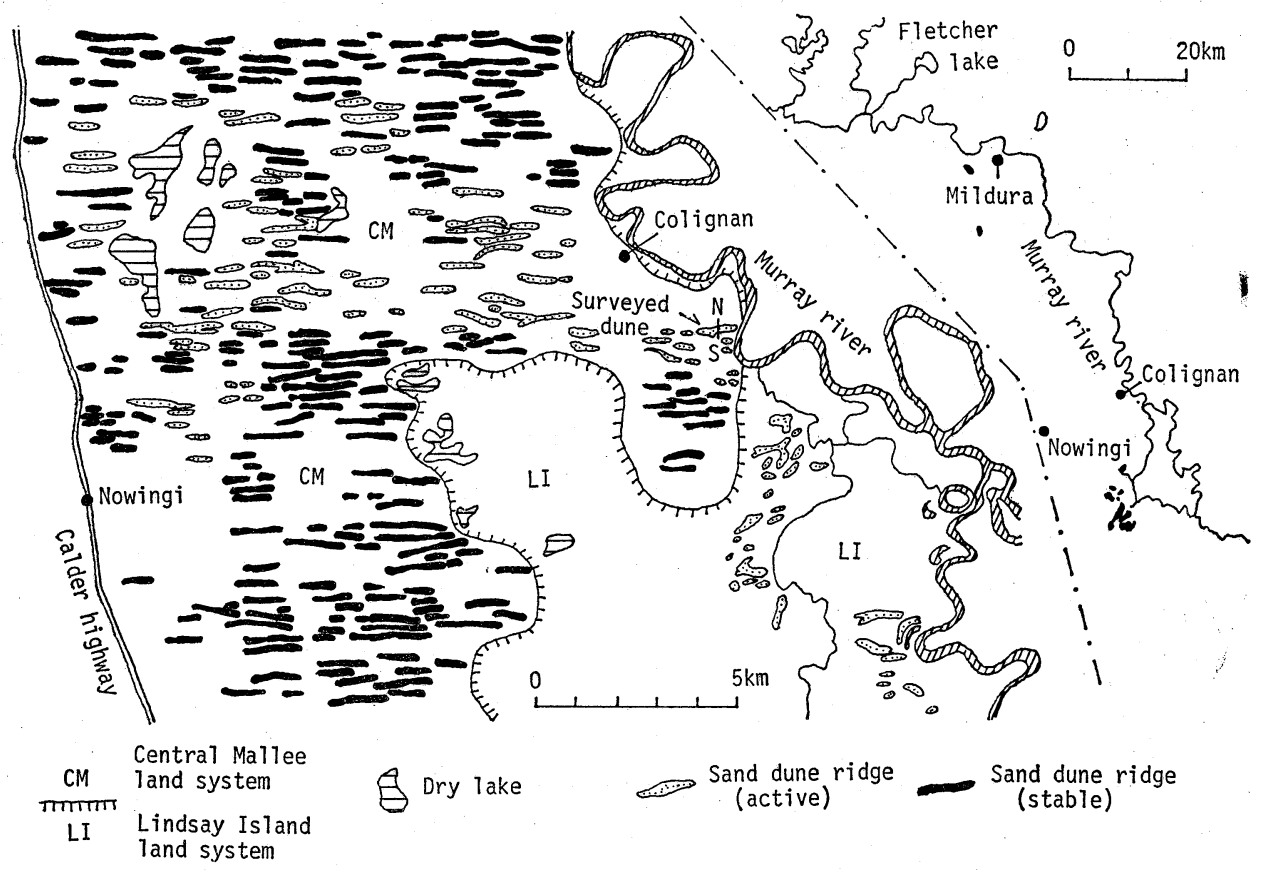

Fig. 3 Distribution of dunes around Mildura

There are distributed orchards of oranges and grape, wheat fields, pastures and Eucalyptus open scrub in the Central Mallee land system which is a dune field up to $10 \mathrm{~m}$ or more high above the Murray riverbed. Any remarkable relationship between dune activity and land use is not recognized, though the local active dunes are scattered mainly in cultivated areas. In the Lindsay Island land system, which occupied the floodplain along the Murray, the Casuarina and Callitris low woodland spreads over, though the river-side forest with tall trees of Eucalyptus spp. stands along stream channels and pastures are distributed in patches. The surveyed local active dune at Colignan is a typical longitudinal dune on the plain about $12 \mathrm{~m}$ high above the Murray riverbed. 
latest Pleistocene dune deposits which accumulated from ca. 25,000 to 13,000 B.P. are corresponding to the Upper Mungo-Zanci Unit defined by Bowler (1971, 1976, 1978), Bowler and Magee (1978), Bowler et al. $(1976,1978)$ and to Woorinen Formation of Twidale $e$ al. (1978). Do and Dy units were formed ca. 6,000 to 3,000 B.P. and 2,000 to 700 B.P., respectively. PD unit is formed by the deposition of sands eroded from Dy and Do units on the windward side of fossil dunes since about 100 B.P. (Suzuki et al., 1982). The local active dune defined above means the dune covered with PD unit from the stratigraphical point of view.

The sands forming dunes have been redistributed in course of their moving from the source areas such as seacoasts, river floors and lake shores to their present positions (Wasson, 1976). Consequently, the thickness of the latest Pleistocene dune deposits, Do and Dy, is different from place to place, respectively. There are actually observed numerous fossil dunes with thin sands of post latest-Pleistocene age less than some tens $\mathrm{cm}$ or without the sands of Holocene age. These fossil dunes are covered mainly with duricrusts or consolidated sand layers just beneath the surfaces in many places.

The local active dunes are distributed in patches over the stable dune field (Figs. 2, 3 and Photo. 1). Although thick sands of the latest Pleistocene and mid-late Holocene ages are observed on the stable dunes covered with vegetation in such areas as national parks and nature reserves, in the caltivated areas such as pastoral lands and agricultural ones, they are revealed to exist in patches on the places where there are relatively thick deposits, more than about $1 \mathrm{~m}$, of the latest Pleistocene dune sands as well as the middle to late Holocene dune sands. These dune sands are either very thin, less than some tens $\mathrm{cm}$, or absent on the surrounding stable dunes. Namely, the occurrence of local active dunes is exclusively restricted on the fossil dunes with thick sand beds of post latestPleistocene dune sands. It can be interpreted, therefore, that the patched distribution of local active dunes is not due to the local difference in climate, but due to the patched distribution of thickness of the sand beds.

\section{Remobilization of dune and its climatological significance}

\section{Relationship between the dune activity and the rainfall fluctuation}

The magnitude and the period of sand movement were evaluated by geologic, geomorphologic, vegetation and hearing surveys. For the analysis of rainfall fluctuation, the report of monthly and yearly rainfall by the Australian Bureau of Meteorology were used.

Since the variation in monthly rainfall is very large from the viewpoints of both regionality and time-series (Gentilli, 1971 a, b; Pittock, 1975 ; Tucker, 1975; Williams, O., 1979), the residual mass curve following the method of Foley (1957) is mainly used for the examination of spatial and time-distribution of rainfall. The residual mass of each month $\left(X_{i, j}\right)$ is calculated by the following formula:

$$
X_{i, j}=\sum_{n=1}^{i} \sum_{m=1}^{j}\left(R_{n, m}-\bar{R}_{m}\right) / \bar{R}_{a} \times 1000
$$

where, $i: i$ th year from the first observation year, 
$j: j$ th month ( 1 to $12 ;$ Jan. to Dec.),

$R_{n, m}$ : monthly rainfall of $m$ th month in $n$th year $(\mathrm{mm})$,

$\bar{R}_{m}$ : mean monthly rainfall of $m$ th month $=\left(\sum_{n=1}^{I} R_{n, m}\right) / I(\mathrm{~mm})$,

$\bar{R}_{a}$ : mean annual rainfall $=\left(\sum_{n=1}^{I} \sum_{m=1}^{12} R_{n}, m\right) / I(\mathrm{~mm})$,

$I$ : duration of observation (year).
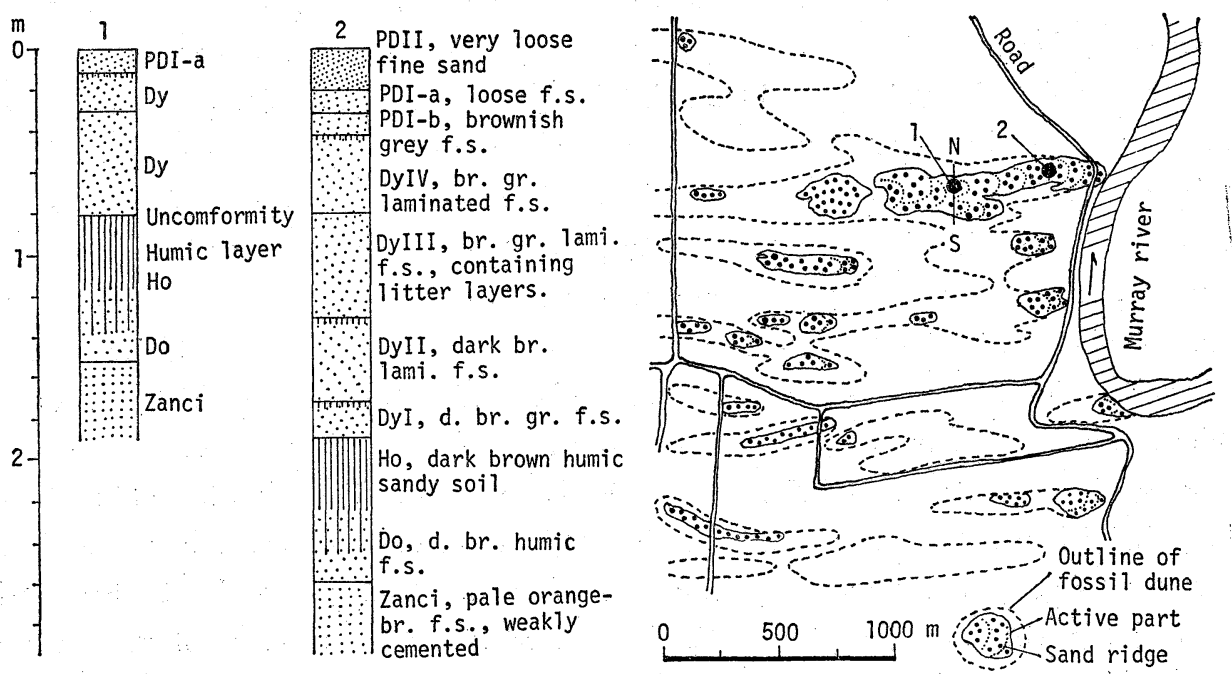

\begin{tabular}{|c|c|c|c|c|c|c|c|c|c|c|c|}
\hline Heigint and & Schrub layer & & $\begin{array}{l}3.5 \\
(20)\end{array}$ & $\begin{array}{l}4.0 \\
(50)\end{array}$ & $\begin{array}{l}1.0 \\
(10)\end{array}$ & . & $\begin{array}{l}1.03 .03 .0 \\
(10)(15)(30)\end{array}$ & $\begin{array}{l}4.0 \\
(30)\end{array}$ & & & $\begin{array}{l}\mathrm{m} \\
\%\end{array}$ \\
\hline coverage & Herb Tayer & $\begin{array}{l}1.0 \\
(25)\end{array}$ & $\begin{array}{l}0.2- \\
(5)(10)\end{array}$ & $\overline{(20)}$ & $\begin{array}{l}-0.2- \\
(10)(15)(10)\end{array}$ & $\begin{array}{l}0.3 \\
(20)\end{array}$ & $(30)(15)(30)$ & $(40)$ & $\begin{array}{l}0.8 \\
(60)\end{array}$ & $\begin{array}{l}0.8 \\
(70)\end{array}$ & $\begin{array}{l}\mathrm{m} \\
\%\end{array}$ \\
\hline $\begin{array}{l}\text { Roughly est } \\
\text { existing pe } \\
\text { plant commu }\end{array}$ & $\begin{array}{l}\text { nated } \\
\text { iod of } \\
\text { ity }\end{array}$ & 2 & 220 & 20 & २० few 5 & few & $\begin{array}{lll}5 & 10 & 15\end{array}$ & 20 & 10 & & years \\
\hline
\end{tabular}

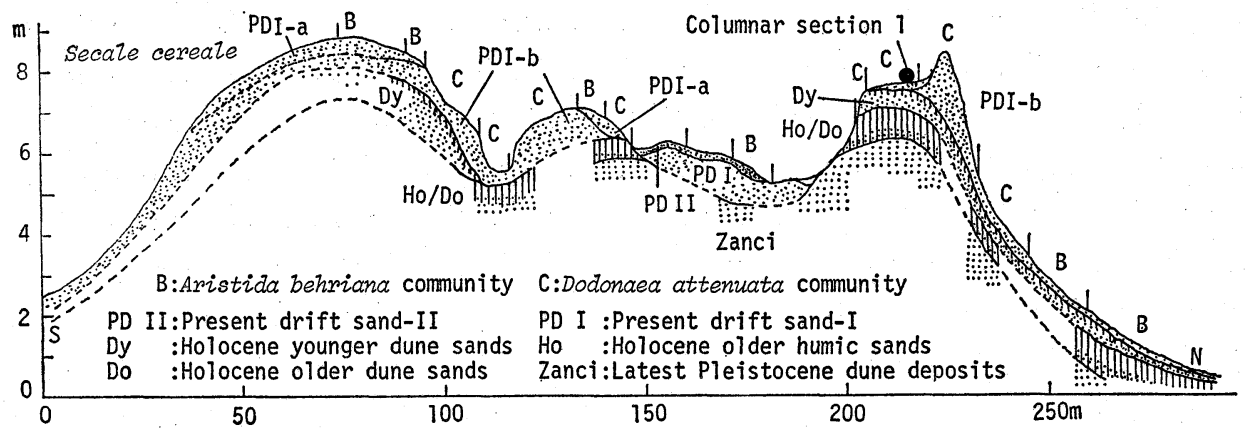

Fig. 4 Columnar sections of the dune sand stratigraphy and a transverse section showing the relationship between geology and vegetation pattern

Present drift sands (PD) and Holocene younger dune sands (Dy) can be divided into at least some layers based on palaeosol and unconformity as shown schematically by columnar section 2. The succession stages of vegetation and the existing periods of plant community differ clearly from part to part of the dune according to the periods of stable stand of each layer of Present drift sands. 
The residual mass curve, which is expressed as RMC in the following sections, has the advantages of both enhancing the long-term trends of rainfall and making the rainfall fluctuations compared with one another among the different regions on the basis of a single criterion of the permillage to the mean annual rainfall of each station.

The Present drift sands(PD) which characterize the local active dunes are divided into several layers by thin humic layers and unconformities at every surveyed dune. Therefore, the phases of dune activities can be revealed based on the dune sand stratigraphy. Some dunes in the areas like Lake Mungo, several places in Eyre Peninsula and in Millicent are reported to be active even before the European settlement. Many dunes, however, became active after the vegetation clearance by the settlers and ${ }^{14} \mathrm{C}$ datings of buried woods in PD unit indicate the ages from 100 B.P. to modern (Suzuki et al., 1982).

The typical relationship between the stratigraphy of PD unit and vegetation can be recognized in a local active dune near Colignan as follows:

PD unit can be divided into at least two layers, that is, PD II and PD I, the latter of which is subdivided into PD I-a and PD I-b, in the local active dune near Colignan, south of Mildura (Photos 1, 2 and Fig. 4). The deposition of PD II is restricted to the crest of the dune, PD I-a and PD I-b lying successively outward. This shows that the active area has diminished in size intermittently. Successional changes of vegetation are clearly observed according to the stage of stabilization of sand. Namely, on the farthest stabilized area on the windward side Acacia ligulata community with a height of some $5 \mathrm{~m}$ is found, of which the existing period is estimated as 30 to 40 years by treering survey. Dodonaea attenuata (Hop bush) community of some $5 \mathrm{~m}$ height is developed on PD I-b, the maximum existing period being estimated as 30 years. There was almost no vegetation 40 years ago over the dune except those places where Acacia ligulata community stands according to the land owner's words and oblique aerial photographs taken in 1939. On PD I-a Dodonaea attenuata community of some 1 to $2 \mathrm{~m}$ height is found, of which the existing period is less than 10 years. Dodonaea attenuata grew on PD I-b to the height of $5 \mathrm{~m}$ and was buried to die under the sands of PD I-a (Photo. 3). Bare land dominates over PD II and only patches of Aristida behriana community or Oenothra striata community exist here and there (Photo. 4). The magnitude in sand drifting of PD II, where sands are mobile at present, was less announced in August 1980 than in 1976 and 1979, when the reconnaissance surveys were made, judging from the coverage of grass, development of sand swell and expansion of drifting sands around the dune.

Through a comparison between rainfall data of Mildura and the history of dune activities revealed by the survey mentioned above, the following conclusion is now obtainable. PD II, PD I-a and PD I-b have become active during the periods of rainfall decrease, (1) 1975, 1976, 1977 79, (2) 1967, 1971 72 and (3) 1925 30,1932 35, 1937, 1943 $\sim 45$, respectively (Fig. 5).

It is further inferred that the dune activities repeated several times are corresponding to the several periods of rainfall decrease, which are revealed by RMC, after the vege- 

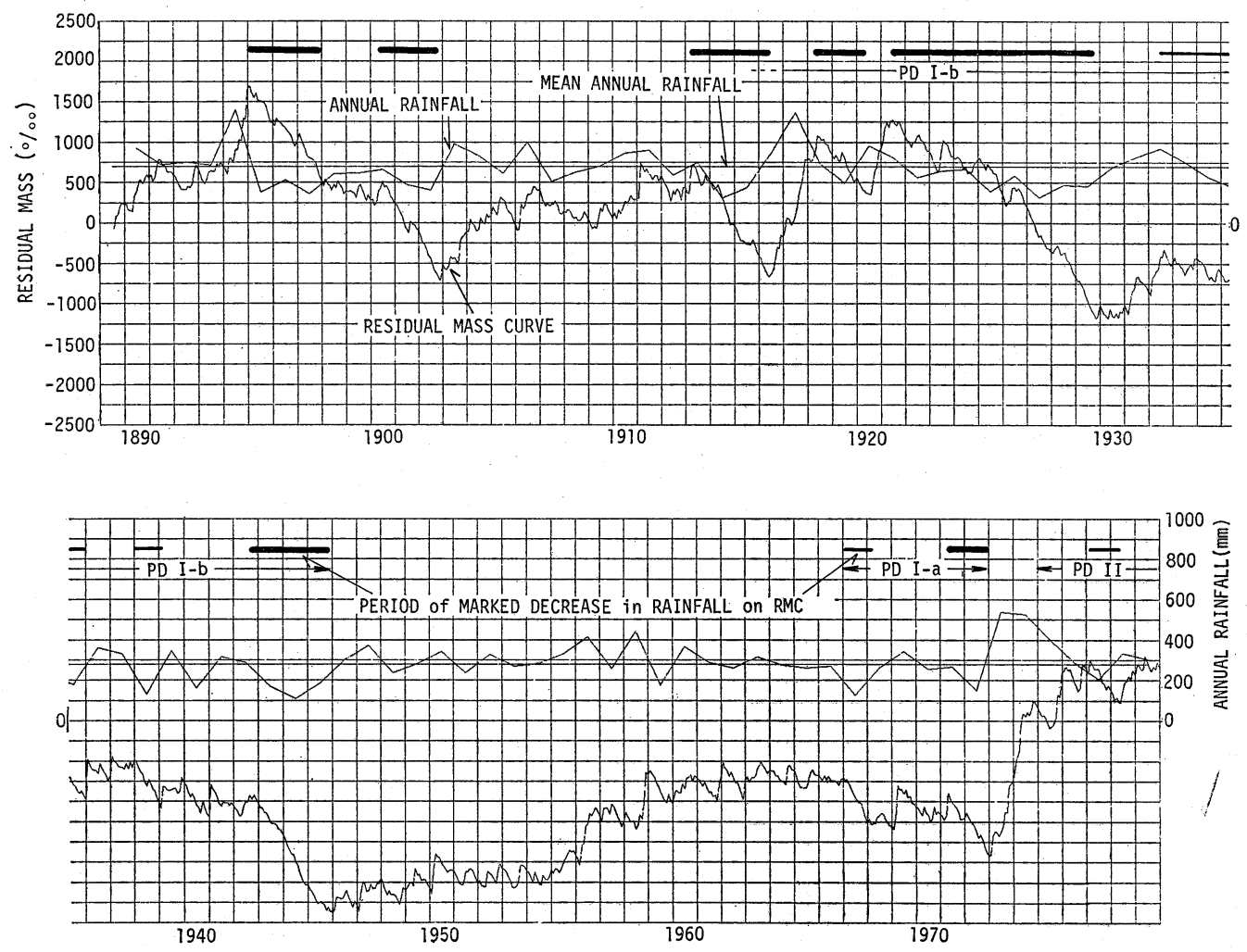

Fig. 5 Relationship between the rainfall fluctuations at Mildura and the dune activities at Colignan

PD II, PD I-a and PD I-b are the layers of Present drift sands divided by the humic sand layers and the unconformities. The age of each layer was determined by both tree-ring survey and hearing survey from the settlers. The "period of marked decrease in rainfall" means the time span when the residual mass curve or rainfall continuously decreased for more than one year resulting in the amount of the sum of the decrease exceeded 500 and/or $600 \%$ of the mean annual rainfall of the station.

tation clearance at the end of the 19 th century. Particularly the period between 1895 and 1903 when the remobilization of dunes started and there was a record of "desolation and dust" near Echuca corresponds to the decreasing period on RMC when the decrease in rainfall amounted to $2,500 \%$ at Mildura and 2,100\% at Hillston.

From the last activity of PD I-b during 1943 45 to 1967, there was no distinct period of decrease in rainfall and dunes were inactive to allow the invasion of vegetation shown by Dodonaea attenuata on PD I-b and buried under PD I-a. In 1973 and 1974, there were the records of maximum precipitation since the beginning of meteorological observation, and an invasion of vegetation onto PD I-a is recognized. Around 1944, sand dunes at Fletcher Lake, north of Mildura, became active and their northern rim advanced for 20 m between 1944 and 1980. Tall Eucalyptus camaldulensis (River red gum) of some $15 \mathrm{~m}$ height with $50 \mathrm{~cm}$ of $\mathrm{DBH}$, once grew in the low marsh, is buried under PD II. Correlative layers to PD I-a and PD I-b are also recognized here. 


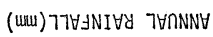

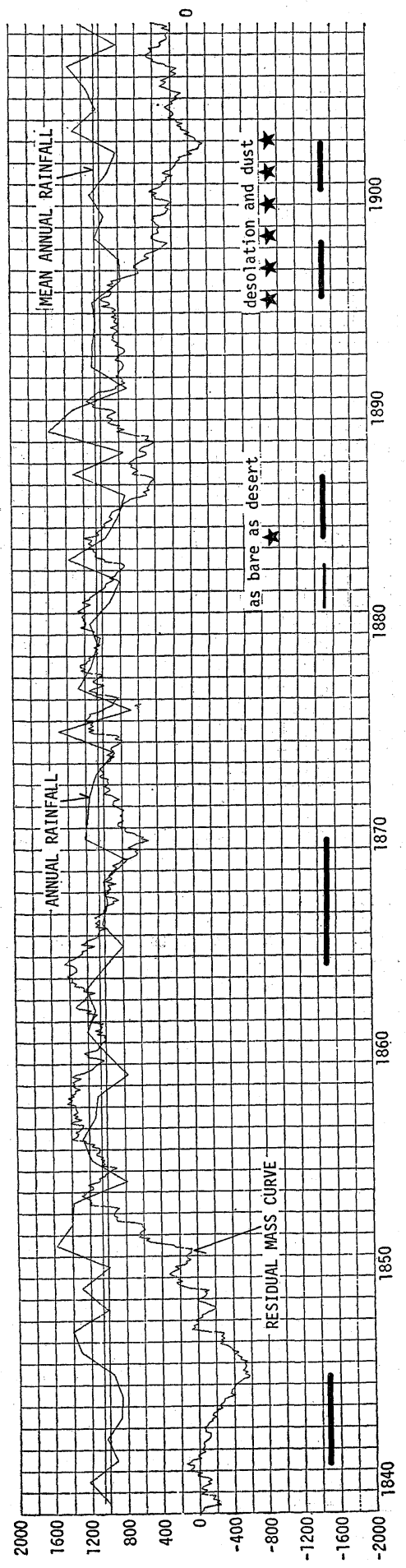

잉 영 웡 웅
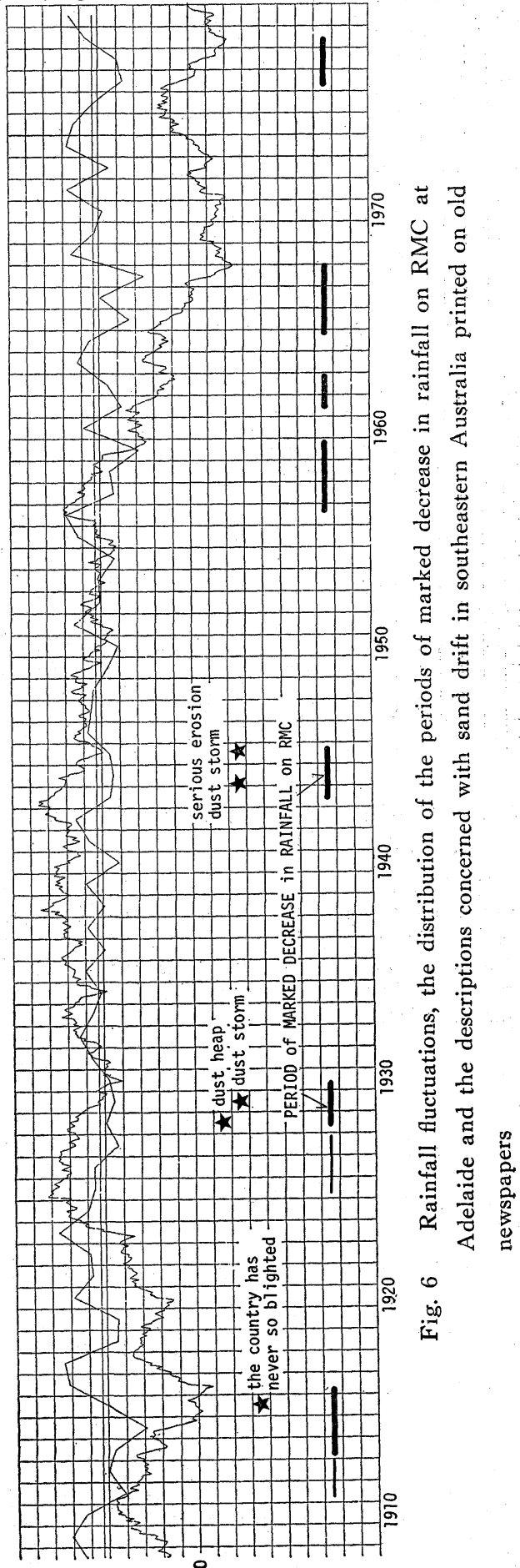

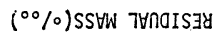


To summarize, it is concluded that the dunes became active during the time when there was a decrease in rainfall amounted to more than 500 and/or $600 \%$ continuously for more than one year.

The authors met a very active sand drift in 1979 and 1980 at Inkerman and Port Wakefield, north of Adelaide. According to the information from the inhabitants, the drift was more active during 1976 77. The RMC of Adelaide endows it with a decrease of more than $700 \%$ (Fig. 6). In the area around Cleve, Eyre Peninsula, the cultivated land became almost desert covered with drifting sands in 1976 and 1977 wherever land was plowed at all. In 1980, however, no trace of it remained. The RMC of Cleve has a decrease of $600 \%$ for $1975 \sim 78$ and a rapid increase thereafter. The recent maximum activity around Port Augusta was inferred to be in 1976 77; less active in 1980 than in 1979. The beginning of dune activities around Lake Grace, Western Australia, according to the information from the residents, was around 1950. It was long after the vegetation clearance in 1928 and corresponds to the period of decrease on the RMC of Lake Grace for more than $1,800 \%$ of the years 1947 to 1958 . The activities observed in 1979 and 1980

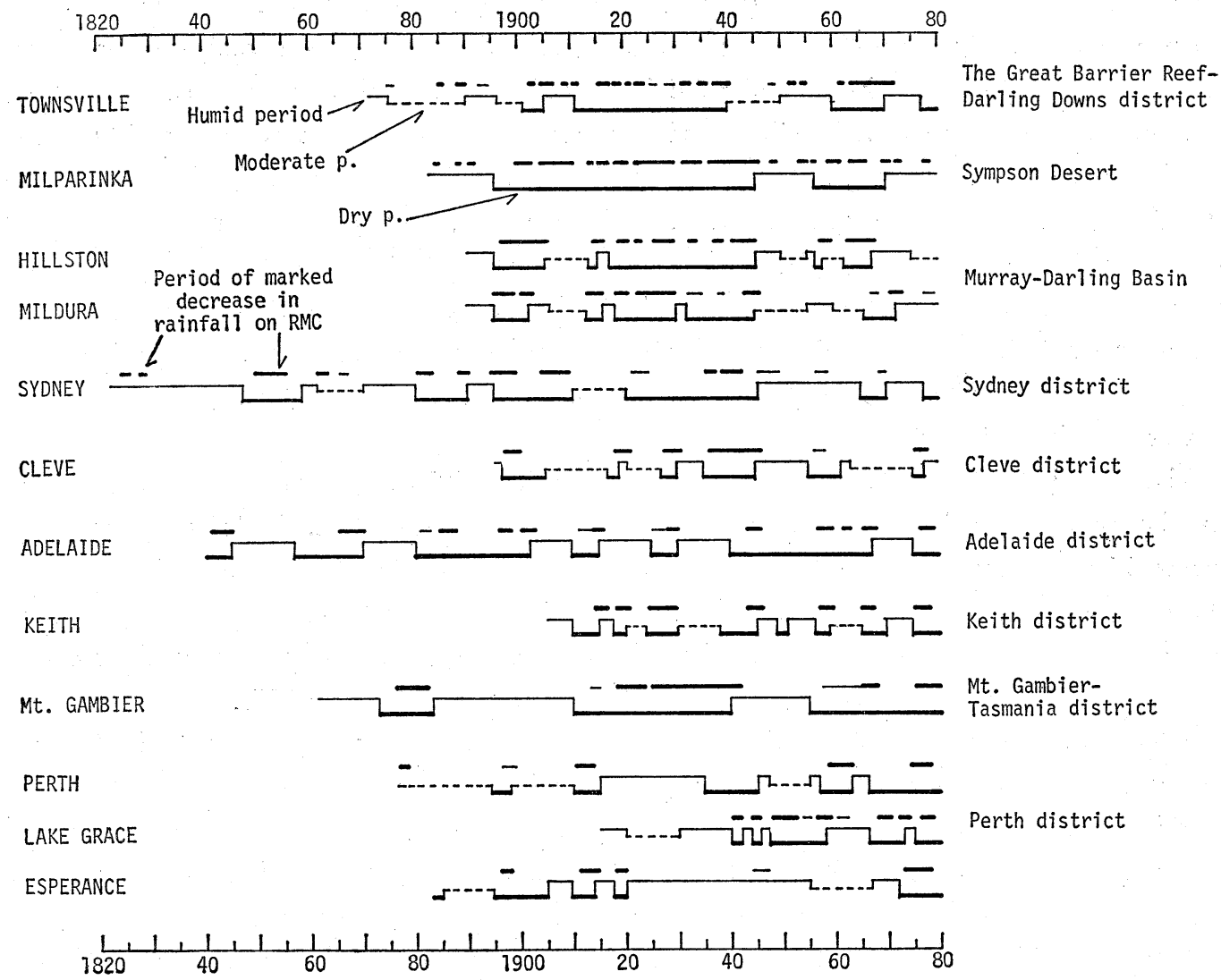

Fig. 7 Distribution of the humid, moderate and dry periods, and of the periods of marked decrease in rainfall, which caused the dune remobilizations, of several regions in Australia 
are corresponding to the periods of decrease of $500 \%$ in 1976 and 1979.

On the other hand, dune activities on the coastal area near Esperance, west coast of Millicent and west coast of Eyre Peninsula are quite strong. The decrease of RMC amounted to $600 \%$ at Esperance during 1974 78, 650\% at Keith during 1976 78 and $500 \%$ at Mt. Gambier during 1974 79, and the rainfall condition for the dune activity has been sufficient.

It is firmly concluded that marked dune activities have been taking place whenever the RMC continuously decreased until the amount of the sum of the decrease exceeded 500 and/or $600 \%$ of mean annual rainfall of the region.

From the above discussion, the periods of intensive dune activities have been inferred for the past from meteorological observation, and are shown in Fig. 7.

\section{Change in frequency of dry climate and the remobilization of dunes}

Dry and humid periods, determined by the analysis of annual rainfall and RMC, are shown in Fig. 7. The division of climatic regions shown in the right column is after Suzuki et al. (1982), which was defined according to both the principal component analysis of monthly rainfall and the similarity of trend of RMC. A dry period means a time span when monthly rainfall deviates negative from the average consecutively for more than twelve months and the annual rainfall as well. RMC descends with time during this period. To the contrary, a humid period is reverse. The time span when monthly rainfall fluctuates frequently around the average in a short interval are defined as the "mod. erate period". These dry and humid periods, however, are not absolute but relative ones. At Adelaide, for example, if the average from 1950 to 1979 (30 years) was taken, most of the time since 1840 became "humid periods", for these 30 years were dry years. Accordingly, it is better to estimate the rainfall trends for a longer period on the basis of comparison of the similarity in the trends with other stations when only a short record of observation is available.

The record of observation available for Keith, near Millicent, is only from 1906, but it can be extrapolated back to 1860 when the observation began at Mt. Gambier through the composition process with the data of Adelaide and Mt. Gambier. In the Lake Grace area, the data from 1915 are available. But the trend is so similar to that of Perth that they can be extrapolated to 1876. Mildura has the data since 1890. They show such a close similarity to Townsville that they can be extrapolated as far back as 1870 .

After such extrapolations of rainfall data, in consideration of magnitude and of synchronism in change of rainfall, it is concluded as follows :

It is since 1880 that the decrease in rainfall, which mobilized dunes, has become frequent. The RMCs tell that the driest period was from the latter half of the 1890's to the first half of the 1940's as pointed out by Gentilli (1971 b). The dry period is continuously distinct from 1940 and from 1955 at Adelaide and Mt. Gambier, respectively, but the Murray-Darling basin, Sydney, Sympson desert and the Great Barrier Reef-Darling Downs districts have a humid phase since 1945 or 1950. In southwestern Australia, the 
decrease in rainfall became frequent since 1890 but with less clarity. In the Lake Grace area, since the beginning of the instrumental observation in 1915, the decrease in rainfall that mobilized dunes did not appear until the 1940's. Such a decrease became frequent long after the vegetation clearance, and then the remobilization of dunes was caused.

In the drought records from the earliest years of the European settlement to $1955 \mathrm{com}$ piled by Foley (1957), such reports as follows are found many times in newspapers: "It was the worst year since 1850 (1897)", "Conditions worse than 1864 or 1902 or 1914 (1944)", "Oldest inhabitants had difficulty in recalling a drier season (1944)", "This had never happened before in 70 years (1946)", etc. These expressions do not indicate the strict magnitude in rainfall deficiency from the climatological point of view but the sensuous magnitude of the "drought". Namely, the magnitudes suggested by these expressions generally the degree of severities not only of dryness but also of damage of crops and pasturage.

Many of these reports started from the beginning of the 19th century while it is known that there have been periods of severe drought around 1864, 1895 1902, 1910 15, 1920 $\sim 30$ and 1940 50 in southeastern Australia. In southwestern Australia, severe droughts occurred from the latter half of the 1880's to the first half of the 1940's. In general, severe droughts became frequent since the end of the 19th century. Particularly it is said that the worst drought in the period from the beginning of the settlement to 1955 throughout southern Australia occurred around 1940, judging from the words of "the worst" and "worse than" which were often printed on newspapers. These severe droughts have very good responses to the "decrease in rainfall" revealed by the analysis of RMC at least during the period of instrumental observation in each region.

The annual rainfall in the early and middle course of the 19th century was more than the mean annual rainfall of the last 30 years from 1950 to 1979 not only for Adelaide, which is now in a dry phase, but also for Sydney which is enjoying a relatively humid phase now.

Drought is partly a human phenomenon. The more the settlers advanced into a drier area, the more they had to face frequent droughts. But the above descriptions tell that it was relatively humid from the end of the 18th century to the end of the 19th century and the dry phase started from the beginning of the 20th century.

All of ${ }^{14} \mathrm{C}$ datings of wood buried in and under $\mathrm{PD}$ unit show the ages from ca. 100 B. P. to modern. This shows that marked sand drifts occurred frequently within the last 100 years. Although the severity of drought does not always correspond to the activity of dunes one to one, such reports as follows tell that marked sand drifts occurred during the severe droughts: "The country was said to be 'as bare as desert' (1884)", "Duststorms occurred almost daily causing the death of thousands of sheep. Sand in the wool weighted the sheep down and they were covered by drifts (1929)", "Erosion was serious in many parts of the state (1945)", etc. (Fig. 6). The remobilization of dunes was caused only by vegetation clearance as shown by the case of Lake Grace. It has been made clear that 
the remobilization has a very good response to the "decrease in rainfall" as was stated in the previous section. And it is since the end of the 19th century or the beginning of the 20 th century that the decrease in rainfall has become frequent throughout the southern part of Australia. Therefore, it is concluded as follows :

The remobilized dunes in the southern part of Australia have increased in both number and coverage with the expansion of the European settlement. The increase, however, was not from the end of the 18th century when the settlers first came, but since the beginning of the 20th century when the dry climate became more frequent. This circumstance continues now at least in the southern part of Australia.

\section{Conclusion}

The active dunes in the Australian continent are classified into two types of areal dis: tribution pattern and activity. One is the "regional active dunes" spreading over the inner arid zone, and the other is the "local active dunes" which are distributed in patches in the southern semi-arid and humid zones with a sharp contrast to the surrounding stable dunes completely covered with vegetation.

The presently drifting sands on the local active dunes are supplied not from seashores or riverbeds, but from the windward erosional areas on fossil dunes themselves. Namely, the local active dune is a result of remobilization of fossil dune.

The strata of dunes since the late Pleiscotene are composed of four units. They are called, from the bottom, latest Pleistocene dune deposits (ca. 25,000 13,000 B. P.), Holocene older dune sands (ca. 6,000 3,000 B. P.), Holocene younger dune sands (ca. 2, 000 700 B. P.) and Present drift sands (after ca. 100 B.P.). Areal correlation between the patched distribution of the local active dunes and the thickness of the dune sands of the latest Pleistocene and mid-late Holocene ages is quite strong. It is confirmed that the patched distribution of local active dunes is not due to the local difference in climate, but due to the patched distribution of thickness of the sand beds.

The Present drift sands which characterize stratigraphically the local active dunes are divided into several layers at every surveyed dune. Both the succession stages of vegeta. tion and the existing periods of plant community on the local active dunes differ clearly from part to part on dune according to the period of accumulation and of stable stand of each layer of Present drift sands.

Although some of local active dunes are reported to have been active even before the European settlement, most of them started sand drifts after the vegetation clearance by the settlers judging from the ${ }^{14} \mathrm{C}$ datings and hearing surveys. Therefore, almost all of them can be called "remobilized dunes". The history of recent dune activities was re. vealed by the geologic, geomorphologic and vegetation surveys mentioned above and confirmed by the hearing surveys from the settlers.

The rainfall fluctuations were induced by the analysis of instrumental records. The residual mass curves were mainly used for the examination of the relationship between the 
rainfall fluctuations and the dune activities. The drought records from the earliest years of the European settlement to 1955 were additionally analyzed from the viewpoints of both the rainfall trend and the dune activity.

The examinations of the relationship between the recent dune activities and the rainfall fluctuations lead to the following conclusions :

The marked dune activities have been taking place whenever the residual mass curve of rainfall continuously decreased resulting in the amount of the sum of the decrease exceeded 500 and/or $600 \%$ of the mean annual rainfall of each region.

It is since 1880 that the decrease in rainfall, which caused the remobilization of dunes, have become frequent over the southern part of Australia. The severe droughts reported on old newspapers, when the marked sand drifts also occurred, have very good responses to the decrease in rainfall revealed by the analysis of rainfall data. The droughts became also frequent since the end of the 19th century and the worst droughts through the period after the European settlement occurred around 1940. The annual rainfalls in the early and middle course of the 19th century were more than the mean annual rainfall of the last 30 years not only for Adelaide which is now in a dry phase, but also for Sydney which is enjoying a relatively humid phase now.

These facts mentioned above tell that it was relatively humid from the end of the 18th century to the end of the 19th century and the dry phase started from the beginning of the 20 th century. The local active dunes have increased in both number and coverage with the expansion of the European settlement. But the increase was not from the end of the 18th century, but since the beginning of the 20th century when the dry climate became more frequent. This circumstance continues now at least in the southern part of Australia.

\section{Acknowledgement}

This study was done under the overseas research grant from the Ministry of Education, Science and Culture of Japan. Professor H. Suzuki, University of Tokyo, who is the organizer of this research, Professor Y. Uesugi, Tsuru University, Professor K. Endo, Nihon University, who both are the members of this research, are gratefully acknowledged for their kindful guidance and helpful advice, and Professor K. Kigoshi, Gakushuin University, for the radiocarbon age determination. For their field work in Australia, they have obtained warm support from various authorities and persons, such as Australian National University, University of New South Wales, University of Melbourne, University of Western Australia, C. S. I. R. O., Bureau of Meteorology, Australia and Departments of National Park, for Environment and of Agriculture and Soil Conservation in many States. The authors extend their greatest appreciation to all whom they contacted.

(Received July 28, 1982 ; Accepted November 8, 1982) 


\section{References}

Bowler, J. M. (1971) : Pleistocene salinities and climatic change: evidence from lakes and lunettes in southeastern Australia. Mulvaney, D. J. and Goison, J. eds. : Aboriginal man and environment in Australia. Aust. Nat. Univ. Press, Canberra, $47 \sim 65$.

Bowler, J. M. (1976) : Aridity in Australia : age, origins and expression in aeolian landfoms and sediment. Earth-Science Rev., 12, 279 310.

Bowler, J. M. (1978): Quaternary climate and tectonics in the evolution of the Riverine Plain, south. eastern Australia. Davies, J.L. and Williams, M. A.J. eds.: Landform evolution in Australia. Aust. Nat. Univ. Press, Canberra, 70 112.

Bowler, J. M. and Magee, J.W. (1978) : Geomorphology of the Mallee region in seme-arid northern Victoria and western New South Wales. Proc. Roy. Soc. Vic. (Symposium on the Murray-Darling river system), 90, 5 26.

Bowler, J. M., Hope, G. S., Jennings, J. N., Singh, G. and Walker, D. (1976) : Late Quaternary climates of Australia and New Guinea. Quat. Res., 6, 359 394.

Bowler, J. M., Stockton, E. and Walker, M. J. (1978) : Quaternary stratigraphy of the Darling river near Tilpa, New South Wales. Proc. Roy. Soc. Vic. (Symposium on the Murray-Darling river system), 90, 79 88.

Dept. National Development of Australia (1973): Landform types in atlas of Australian resource. 2nd series.

Foley, J.C. (1957): Droughts in Australia-Review of records from earliest years of settlement to 1955. Bull. Bur. Met. Aust., No. 43, 1 281.

Gentilli, J. (1971a): The main climatological elements. Gentilli, J. ed.: Climates of Australia and New Zealand (World Survey of Climatology, 13). Elsevier, Amsterdam, 119 188.

Gentilli, J. (1971b) : Climatic fluctuations. Gentilli, J. ed. : Climates of Australia and New Zealand (World Survey of Climatology, 13). Elsevier, Amsterdam, 189 211.

Gilbertson, D.D. (1981) : The impact of the past and present land use on a major coastal barrier system. Appl. Geogr., 1, 97 119.

Land Conservation Council (1974): Report on the Mallee study area. Victoria Government, Melbourne, $263 \mathrm{p}$.

Learmonth, N. and Learmonth, A. (1971) : Regional landscapes of Australia. Heinemann Educational Books, London, $493 \mathrm{p}$.

Ohmori, H. (1980): Removement of dunes and its climatic significance in Australia. Jour. Geogr. (Japan), 89, 167 178 (In Japanese with English abstract and illustrations).

Pittock, A. B. (1975) : Climatic change and the patterns of variation in Australian rainfall. Search, 6, 498 504.

Raymond, R. and Morrison, R. (1979) : Australia: the greatest island. Lansdowne Press, Sydney, $352 \mathrm{p}$.

Suzuki, H., Uesugi, Y., Endo, K., Ohmori, H., Takeuchi, K. and Iwasaki, K. (1982) : Studies on the Holocene and recent climatic fluctuations in Australia and Ner Zealand (Scientific Report of overseas research in Australia and New Zealand). Dept. Geogr. Univ. Tokyo, Tokyo, 166 p.

Thom, B. G. (1978) : Coastal sand deposition in southeast Australia during the Holocene. Davies, J.L. and Williams, M. A.J. eds.: Landform evolution in Australia. Aust. Nat. Univ. Press, Canberra $197 \sim 214$. 
Thom, B. G., Bowman, G. M. and Roy, P.S. (1981) : Late Quaternary evolution of coastal sardd barriers, Port Stephens-Myall lakes area, central New South Wales, Australia. Quat. Res., 15, $345 \sim 364$.

Tucker, G. B. (1975) : Climate : is Australia's changing? Search, 6, 323 328.

Twidale, C. R., Lindsay, J. M. and Bourne, J. A. (1978): Age and origin of the Murray river and gorge in South Australia. Proc. Roy. Soc. Vic. (Symposium on the Murray-Darling river system), 90, $27 \sim 42$.

Wasson, R. J. (1976) : Holocene aeolian landforms in the Belarabon area, S. W. of Cobar, N. S. W.. Jour. Proc. Roy. Soc. N.S. W., 109, 91 101.

Wasson, R.J. (1979) : Sedimentation history of the Mundi Mundi alluvial fans, western New South Wales. Sedimentary Geol., 22, 21 51.

Ward, W. T. and Russell, J.S. (1980): Winds in southeast Queensland and rain in Australia and their possible long-term relationship with sunspot number. Climatic Change, 3, 89 104.

Williams, M. (1978): Desertification and technological adjustment in the Murray Mallee of south Australia. Search, 9, 265 268.

Williams, O. B. (1979) : Ecosystems of Australia. Goodall, D. W. and Perry, R.A. eds.: Arid-land ecosystems, 1. Cambridge Univ. Press, London, 145 212. 


\section{オーストラリア南部における最近の砂丘活動と降水量変動との関係}

\section{大森博雄 $*$ ・岩崎一孝 $* *$ ・武内和彦 $* * *$}

オーストラリア南部には, 最近活動を再開した砂丘が数多くみられる.この再活動については, 植生破壊を

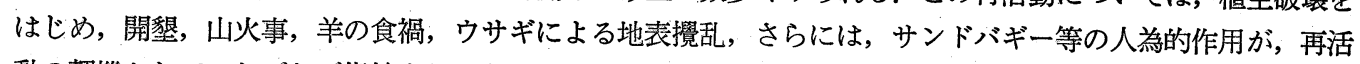
動の契機として, しばしば指摘されてきた. しかしながら, 砂丘活動と気候変動との関係はいまだ系統的には 検討されていない，すなわち，砂丘活動と気候変動との関係を，広域的かつ個々の地域ごとに解明し，さらに， 砂丘活動史と関連させて考察した研究はいまだみられない，それゆえ，上記の再活動の契機となった人為的活 動をいかに評価すべきか，また，再活動の主たる原因を何に求めるべきであるか，についてはほとんど明らか にされていない. 本稿は, 地形・地質, 植生ならびに聴き取り調查による最近の砂丘活動の変遷と, 観測資料 および旱鬽資料の分析から得られた降水量変動との関係を検討し, 気候的側面から砂斥の再活動について考察 した. 結果を以下に示す.

再活動した砂丘は, 大陸規模でみた場合, 南部の半乾燥および湿潤地帯に集中してみられる.さらに, これ らの再活動砂丘は, 固定砂丘群中にパッチ状に分布する. オーストラリア南部の砂丘は, 少なくとも更新世後 期以降, 何度か形成され, 新旧の砂丘が混在している. また形成期ごとに砂の再配分が行なわれ, 更新世末期 から完新世後期にかけて形成された砂丘の砂の厚さは, 地域的に大きく異なる. 再活動砂丘の分布は, 更新世 末期以降形成された砂丘砂層の厚さと関係し, 厚い所に限られている. すなわち, 再活動砂丘のパッチ状分布 は, 気候の地域的差異によるものではなく, 更新世末期以降の砂丘砂層の厚さのパッチ状分布によると考える. 現在活動している砂丘のいくつかは, 白人の入植以前から活動していたことが知られているが，大部分は白 人入植後の植生破壊以降に再活動したものである.

腐植層や不整合に基づいた砂丘砂層序, 各時期の砂斥砂上の植生調査, および聴き取り調查によって決定し た最近の砂丘活動と降水量変動との関係を検討し，以下の結果を得た.

1 年以上にわたって, 累積月降水量残差が減少し，その減少量が平均年降水量の 500 なし $600 \%$ 以上になる と, 顕著な砂丘活動が発生する.

アデレード，シドニーを除くと，気象観測が開始されたのは，多くの地域で1870年代以降である.これらの 気象デー夕によると，砂丘活動を引き起こすような顕著な降水量減少期が頻発するようになるのは, 1800 年代 の末期以降である.

白人入植直後の 1700 年代末ないし，1800年代初頭以降の降水量変動傾向に関しては，農牧業の被害状況や飛 砂現象が記載されている旱鬽資料を検討した. その結果, 大きな旱魅も，1800年代末期以降に頻発しているこ とがわかった. 大きな旱䰠時には, 飛砂現象も顕著であった，また，気象データのある期間においては，記載 された大きな旱魅は,「顕著な降水量減少期」と一致している. アデレード, シドニーの気象観測データは, 1800年代前・中期は比較的湿潤で, 1800年代末以降, 乾燥気候が頻発することを示している.

以上の検討から, オーストラリア南部における砂丘の再活動について以下のように考える.

白人が最初に入植した18世紀末から19世紀末までは, 比較的湿潤であった. 19世紀末ないし20世紀初頭以降 に, 乾燥気候が頻発するようになったが，この時期になって，砂丘の再活動は規模および数において顕著に增 妿した．すなわち，砂丘の再活動は乾燥気候の頻発する時代の現象であり，この状態は，大局的には，少なく ともオーストラリア南部では, 今日も継続しているとみることができる.

\footnotetext{
* 東京大学・理学部 $* *$ 東京大学・院 $* * *$ 東京都立大学・理学部
} 


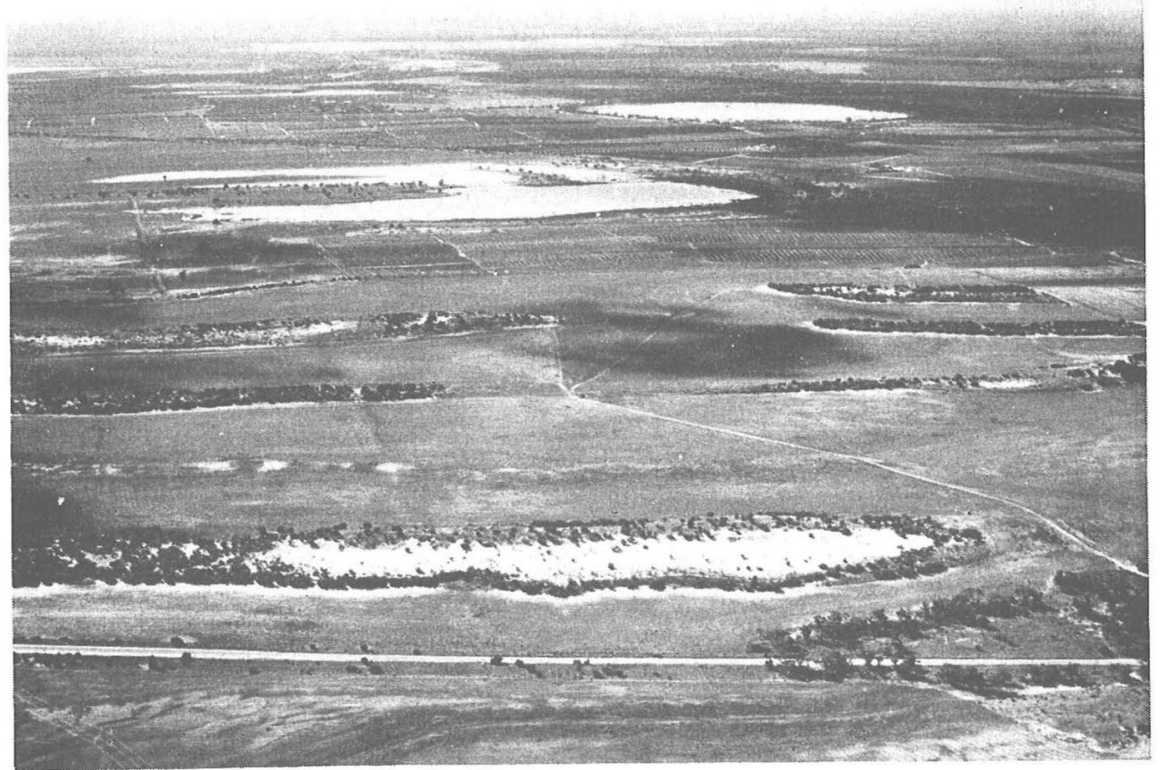

Photo. 1 Distribution of local active dunes around Mildura

The local active dunes are found to exist in patches in the area where the longitudinal dunes are distributed in parallel over orchards, wheat fields and pastures.

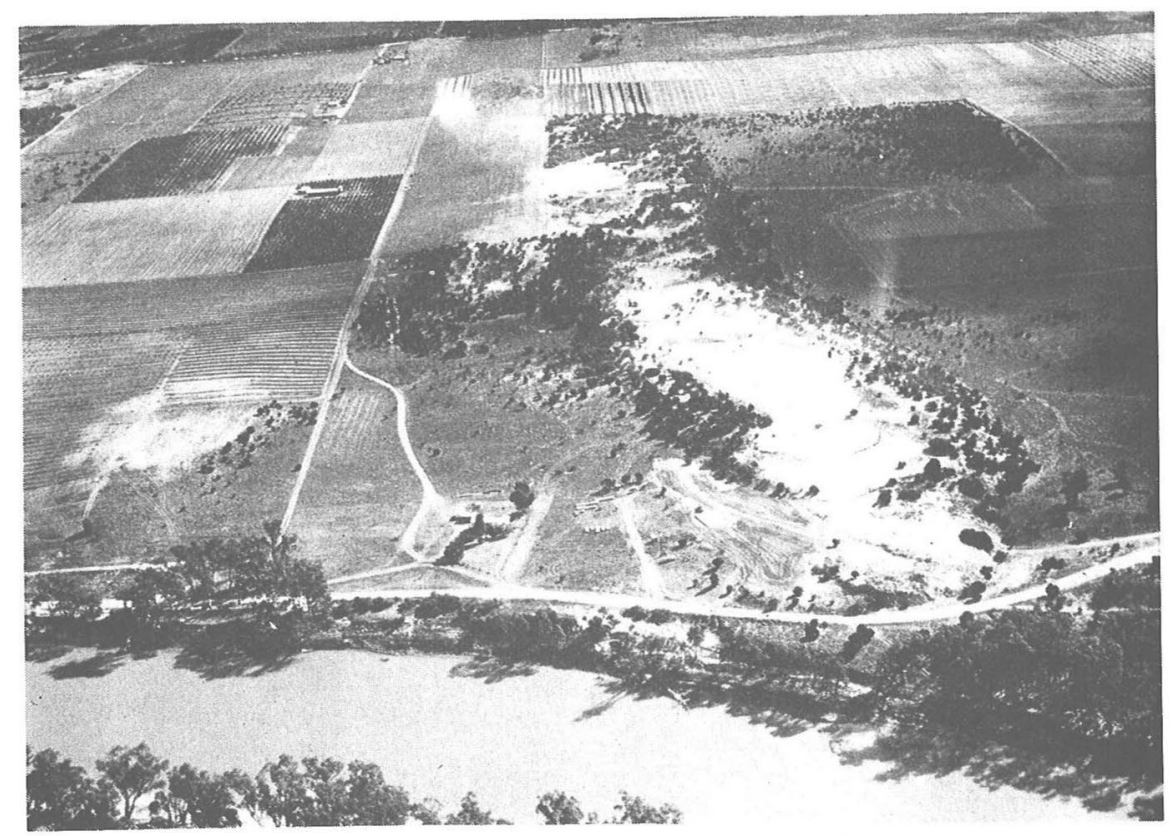

Photo. 2 Oblique aerial view of the surveyed dune at Colignan westwards across the Murray river; showing many swells of sands formed on the dune 


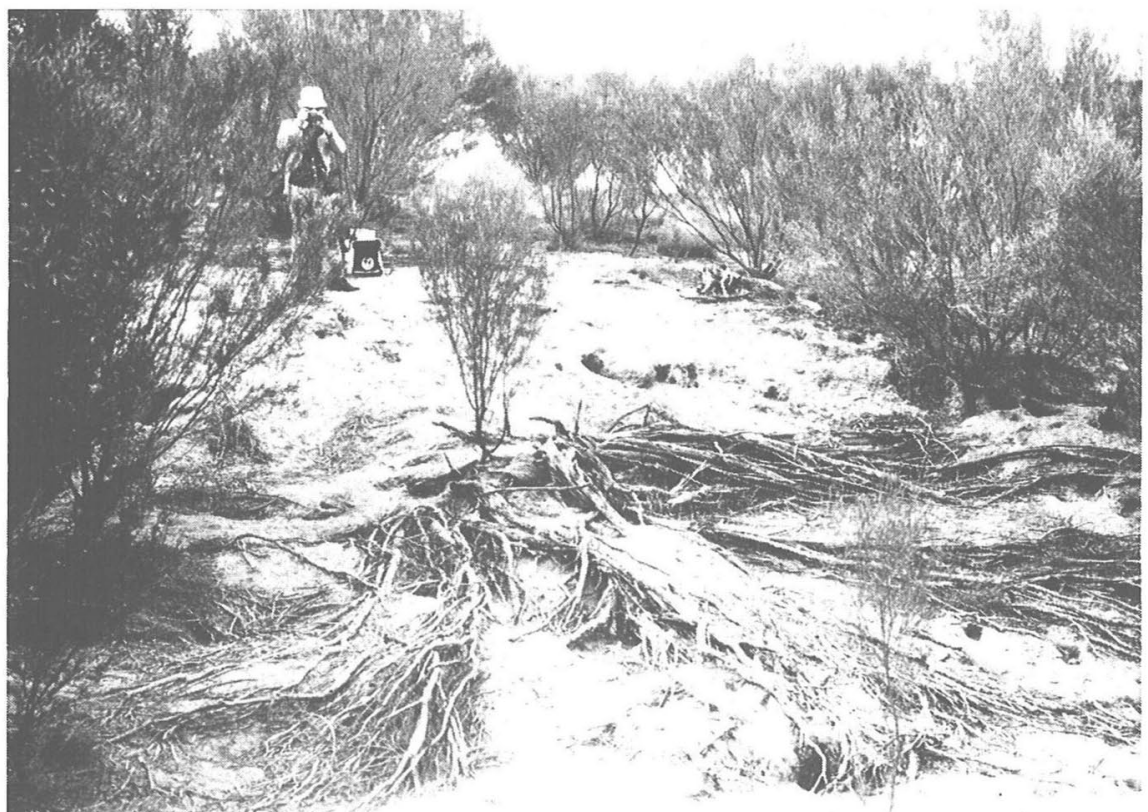

Photo. 3. Dodonaea attenuata community on PD I-b buried by PD I-a

It was revealed that PD I-b was stabilized around 1950 and the drift of PD I-a started about 1970 by the tree-ring survey and by the hearing survey.

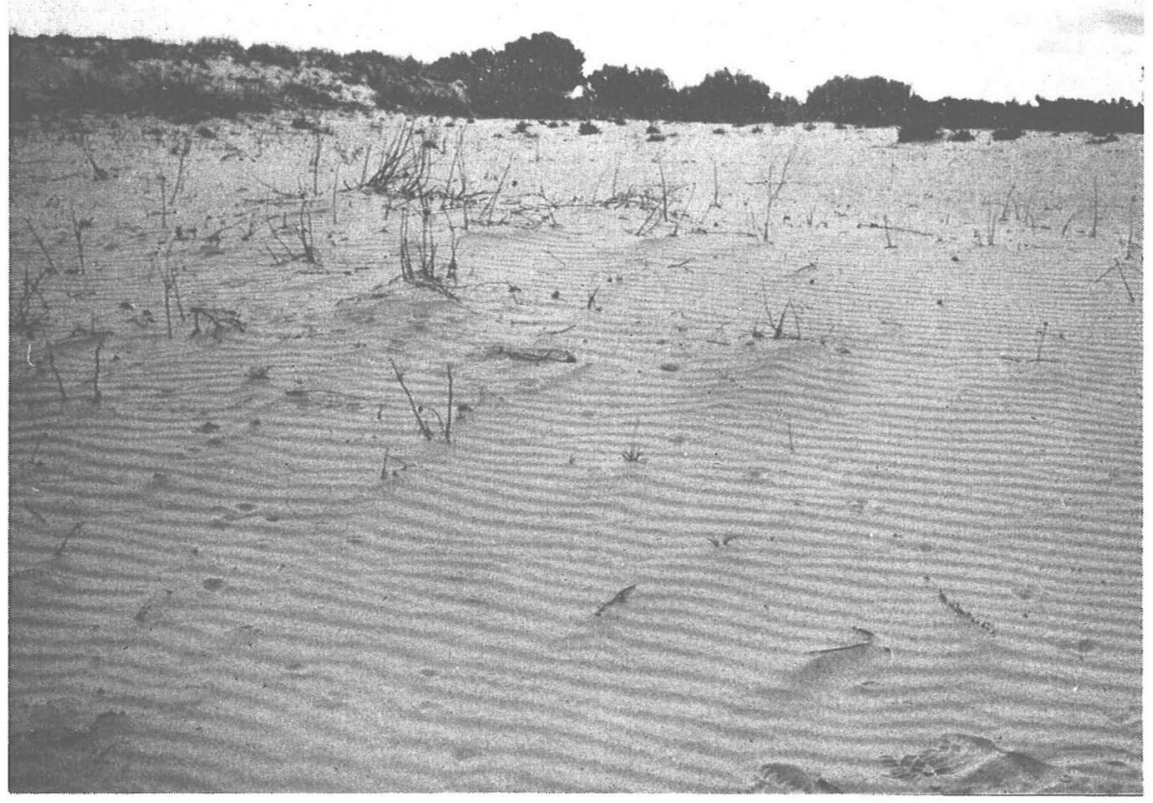

Ploto. 4. The vegetation on PD II

Bare land dominates over PD II and only patches of Aristia behriana community or Oenothra striata community exist here and there. 